\title{
Impact of UN General Assembly Resolutions on the Circulation and Use of Weapons on Earth and in the Cosmos
}

\author{
Serhiy Didenko \\ Doctor of Law, Professor, Honored Lawyer of Ukraine, \\ Director of the Kherson Institute of \\ "Interregional Academy of Personnel Management" \\ (Kherson, Ukraine) \\ E-mail: sergii_didenko@ukr.net
}

\begin{abstract}
In the paper, the author has analyzed the international experience of administrative and legal support for the circulation and use of weapons on Earth and in the Cosmos. The analysis carried out by the author testifies to the global nature of this issue, which has found its international legal settlement at the level of the UN and the EU. It is in accordance with the resolutions of these organizations that in the majority of countries of the world legally legalized the circulation and use of weapons on Earth and in the Cosmos. It has been found that, in accordance with Article 38 of the Statute of the International Court of Justice, which contains "the sources of international law," not all resolutions of the General Assembly have a quasi-legislative force. Therefore, if the resolutions of the Assembly that ensure the circulation and use of weapons on Earth have quasi-legislative competence, they therefore make a significant contribution to the world legal order, then the resolutions of the Assembly in the Cosmic activities have a limited legal status. In fact, administrative and legal support for the circulation and use of weapons in the Cosmos is unregulated.
\end{abstract}

Keywords: weapons; circulation of weapons, administrative and legal support, General Assembly resolution, quasi-legislative force

\section{Вплив резолюцій Генеральної Асамблеї ООН на забезпечення обігу та застосування зброї на Землі і в космосі}

\section{Діденко, Сергій Володимирович}

Доктор юридичних наук, професор, Заслужений юрист України, директор Херсонського інституту «Міжрегіональної Академії управління персоналом»

(Херсон, Україна)

(C) Didenko, Serhiy, 2018 
У статті проаналізовано міжнародний досвід адміністративно-правового забезпечення обігу та застосування зброї на Землі і в космосі. Проведений автором аналіз свідчить про глобальний характер иієї проблематики, яка знайшла своє міжнародно-правове врегулювання на рівні ООН та ЄС. Саме у відповідності до резолюиій ции організаиій у більшості країнах світу забезпечується юридична легалізачія обігу та застосування зброї на Землі і в космосі. Виявлено, шо відповідно статті 38 Статуту Міжнародного Суду у якій містяться «джерела міжнародного права», не всі резолюиії Генеральної Асамблеї мають квазі-законодавчу силу. Тому, якщяо резолючиї Асамблеї які забезпечують обіг та застосування зброї на Землі мають квазі-законодавчі компетенції, тому вносять вагомий внесок у світовий правовий порядок, то резолюиії Асамблеї у космічній діяльності мають обмежений законодавчий статус. По суті, адміністративно-правове забезпечення обігу та застосування зброї в космосі є неврегульованим.

Ключові слова: зброя, обіг зброї, адміністративно-правове забезпечення, резолючії Генеральної Асамблеї, квазі-законодавчі компетенції.

Received: January 16, 2018; accepted: February 13, 2018

Advanced Space Law, Volume 1, 2018: 33-41.

https://doi.org/10.29202/as1/2018/1/4

\section{Постановка проблеми}

Питання правового регулювання обігу зброї на Землі і в космосі залишаються актуальними для усіх держав світу. Аналіз адміністративно-правового забезпечення обігу та застосування зброї на Землі на міжнародному рівні засвідчує його інтенсивне удосконалення. Стратегію розвитку адміністративно-правового забезпечення обігу та застосування зброї на Землі регулюють резолюції Генеральної Асамблеї ООН. Наприклад, Резолюція 3314 (XXIX) у Статті 1 дає визначення агресії: «Агресія — це використання збройною сили державою проти суверенітету, територіальної цілісності або політичної незалежності іншої держави, або будь-яким іншим чином, що суперечить Статуту Організації Об'єднаних Націй, викладеному в цьому Визначенні» ${ }^{1}$ [Definition of Aggression, 1974]. Відповідно до цього визначення розробляються статті з коментарями, які дозволяють Міжнародному Суду, а також на рівні систем правових норм держав, забезпечувати правове регулювання обігу та застосування зброї на Землі і в межах держави. Наприклад, у «Проекті статей про наслідки збройних конфліктів для міжнародних договорів $з$ коментарями» зібрані статті, відповідно яких на міжнародному рівні визначається адміністративно-правове забезпечення наслідків застосування зброї на Землі [Draft articles, 2011].

Відповідно до Річарда Фалька, який є почесним професором міжнародного права в Прінстонському університеті, резолюції Генеральної Асамблеї, які регулюють стратегію правового забезпечення обігу та застосування зброї на Землі мають квазі-законодавчу силу, яка дозволяє їм регулювати світовий правовий порядок [Falk, 1996]. Але в той же час, резолюції Асамблеї відповідно адміністративно-правового забезпечення обігу та

${ }^{1}$ Переклад автора 3 оригіналу «Aggression is the use of armed force by a State against the sovereignty, territorial integrity or political independence of another State, or in any other manner inconsistent with the Charter of the United Nations, as set out in this Definition» [Definition of Aggression, 1974]. 
застосування зброї у космосі мають обмежений законодавчий статус. Як засвідчує дослідження автора, стратегія розвитку законодавчої бази до обігу та застосування зброї у космосі фактично відсутня.

Дослідженням проблематики адміністративно-правового забезпечення обігу та застосування зброї на Землі прямо чи побічно присвячені праці багатьох науковців. Наприклад, В. Б. Авер'янова, В. В. Зуя, В. І. Олефіра, Е. Ф. Шамсумової, О. М. Бандурки, Р. А. Калюжного, та ін. Крім того, вагоме значення мають праці авторів, які розглядали правові засади регулювання зброї як в Україні, так і за ії межами: П. Д. Біленчука, А. Д. Благова, О. М. Бокія, В. А. Гуменюка, А. В. Кофанова, І. А. Кузнєцової, О. М. Піджаренко, О. Ф. Суляви, М. П. Федорова, О. С. Фролова, Е. Д. Шелковникової та ін.

Мета статті - розглянути вплив резолюцій Генеральної Асамблеї ООН на забезпечення обігу та застосування зброї на Землі і в космосі, а також виявити відмінності.

\section{Виклад основного матеріалу}

Автор погоджується з О. Романовим, який зазначає, що головним суб'єктом, який всебічно та найактивнішим чином переймається питанням правового забезпечення обігу зброї на Землі і в космосі, є Організація Об’єднаних Націй [Романов, 2005: с. 36]. Зрозуміло, що до ії відання, окрім проблеми незаконного обігу зброї також відноситься і іï застосування.

За даними ООН, у 2015 році у світі нараховується 800 млн. одиниць вогнепальної зброї. Small Arms Survey ще у 2009 році заявила, що цієї зброї щонайменше 875 млн. Це на 40\% більше, ніж автомобілів у світі. І лише 25\% зброї перебуває у мілітарних організаціях (армія, поліція). Близько 40\% перебуває в особистому користуванні нелегально. За оцінками ООН, з легальних джерел на «чорний» ринок потрапляє 670 тис. одиниць вогнепальної зброї на рік. Тому варто замислитись над тим, що зростання кількості легальної зброї, в тому числі розширення іiі асортименту і спрощення процесу придбання — прямий шлях до зростання обсягів нелегального обігу зброї [Цивільна зброя,2015: c. 5].

На думку О. Романова, так як наразі, існує велика кількість різноманітних документів, присвячених розв'язанню проблеми незаконного і стрімкого розповсюдження вогнепальної зброї на Землі і в космосі, що були прийняті світовою спільнотою протягом двох останніх десятиліть. Вони складають колосальний теоретичний і практичний правовий досвід [Романов, 2005: с. 36]. А. Корнієць зазначає, що певні напрацювання в цьому напрямі з'явилися після розроблення проекту Міжнародного кодексу поведінки щодо постачання зброї, який підготувала група лауреатів Нобелівської премії миру. Цим документом визначено зброєю: всі види зброї, бойову техніку, компоненти та системи доставки, серед них: бойові танки, бойові броньовані машини, військові літаки, артилерійські системи, військові гелікоптери, ракети, майно воєнізованої поліції, міномети, кулемети й автомати, гвинтівки, пістолети, протитанкові гармати, міни, гранати, касетні бомби та всі види боєприпасів. Цей законопроект є нічим іншим, як продовженням Свропейської конвенції з контролю за придбанням і зберіганням вогнепальної зброї приватними особами, в якій звернуто увагу на той факт, що вогнепальна зброя є джерелом підвищеної небезпеки, а її поширення не знає кордонів [Корнієць, 2011, с. 88].

На нашу думку, саме 3 цих міжнародних нормативно-правових актів потрібно черпати основоположні засади адміністративно-правового забезпечення обігу та застосу- 
вання зброї на території України, орієнтуючись вже на розроблені світовою спільнотою стандарти та правила. Необхідно відмітити, що в них не вказується про правовий режим холодної, холодної метальної, газової, пневматичної, запалювальної та нелетальної зброї.

В окремих країнах питання вільного володіння зброєю не піднімається на офіційному рівні, оскільки там, є ймовірність того, що якщо озброїти народ, то він скине тоталітарну диктатуру. Принцип вільного носіння та зберігання зброї відносяться одне до одного як демократія проти тоталітарної системи. Озброєні законослухняні громадяни представляються небезпечними тільки тим, хто бажає ними правити. Відібрати в людини захист в тих випадках, коли суспільство його дати не може, означало б зовсім знищити об'єктивну рівність між людьми. Там, де громадяни реально не мають прав, гарантованих конституцією і міжнародними нормами права, а тільки ті, які дарує їм влада,- ніякі вони не громадяни, а піддані, озброювати яких небезпечно. Режим завжди боїться збройного народу, набагато більше, ніж іноземних армій [Трунов, 2004].

На сьогодні більшість пострадянських країн мають власні закони про зброю: Росія — Закон «Про зброю», вперше прийнятий у 1993 р. (другий у 1996 р., нині готується третя редакція); Білорусь — Закон «Про зброю», прийнятий у 2001 р.; Естонія — Закон «Про зброю», прийнятий у 1996 р.; Латвія - Закон «Про зброю», прийнятий у 2002 р.; Молдова - Закон «Про контроль над індивідуальною зброєю», прийнятий у 1994 р.; Азербайджан - Закон «Про службову та цивільну зброю», прийнятий у 1997 р.; Киргизія — Закон «Про зброю», прийнятий у 1999 р.; у Грузії на сьогодні закон відсутній, але громадяни мають право зберігати за місцем проживання короткоствольну нарізну зброю з метою самозахисту. I, як слушно зазначає С. Параниця, для порівняння, в Україні- попереднє схвалення проекту Закону України «Про зброю» в першому читанні здобуток національного законодавства. І це, незважаючи на те, що Комітет Верховної Ради України з питань законодавчого забезпечення правоохоронної діяльності спільно 3 Кабінетом Міністрів України доопрацював зазначений законопроект [Параниця, 2009].

Провівши відповідні дослідження, Г. Герега, О. Зарубінський, Б. Петренко, Р. Старовойтенко, дійшли висновку, що у країнах Євросоюзу простежується відносно низький інтерес громадян до зброї, кожні дев'ять з десяти громадян не мають і не планують мати зброю для самозахисту. Країною з найбільшою у відсотках кількістю зброї для самозахисту в Свросоюзі є Литва, однак варто зазначити, що в цій країні в абсолютних показниках лише 0,7 на 100 громадян мають цивільну зброю (найнижчий показник в Свропі), а показники індексу вбивств на 100000 населення вищі за розвинені країни Свропейського Союзу. Серед власників зброї лише 14\% європейців придбали іiї для самозахисту. Свропейські країни вирізняються найбільшою безпекою у світі і мають найнижчі показники індексу вбивств на 100000 населення. Загальним трендом для Євросоюзу $\epsilon$ посилення відповідальності за нелегальне чи надмірне використання вогнепальної зброї, особливу увагу приділено профілактиці масових невмотивованих убивств, проявам тероризму тощо [Цивільна зброя, 2015: с. 61].

Слід зазначити, що у 2013 році Бельгія залишалась єдиною країною Євросоюзу, в якій була можливість вільного придбання вогнепальної зброї. Однак зростання кількості резонансних вбивств, змусили уряд цієї країни, під тиском громадськості, повністю заборонити вільний продаж. 680 видів найменувань зброї, в тому числі фольклорна, декоративна, історична тепер вимагають проходження дозвільної системи. Стрілецькі асоціації Бельгії відчайдушно протестували, зібрали 15000 підписантів під петицією 
проти введення дозвільної системи (кількість підписантів велика для Бельгії), подали до апеляційного суду, однак уряд проявив жорсткість і не допустив навіть дискусію щодо цього питання [Цивільна зброя, 2015: с. 62].

Між тим, саме стрілецька зброя стала однією з головних проблем для міжнародної спільноти та безпеки у світі у зв'язку з їі надмірним розповсюдженням у всіх регіонах земної кулі. У локальних війнах та конфліктах така зброя користується найбільшим попитом. Причина такої популярності полягає в тому, що: стрілецька зброя має відносно низьку ціну; має смертельну дію; зручна у перевезенні, іiі легко сховати; може використовуватися протягом тривалого терміну; проста у користуванні [Романов, 2005, c. 37].

Зупинимось більш детально на стані адміністративно-правового забезпечення обігу та застосування зброї в деяких країнах. Перш за все, почнемо із Сполучених Штатів Америки, де обіг і застосування зброї завжди був ліберальним в порівнянні із іншими країнами. Як зазначає А. Корнієць, законодавець країни завжди вважав, що право ходити озброєним є прерогативою вільних людей. Засновники держави визнавали його безперечним і поклали в основу американської політичної системи. У формулюванні Т. Джефферсона йдеться про те, що «це право та обов’язок усіх людей — завжди бути озброєними» [Корнієць, 2011: с. 89]. При цьому, друга поправка Конституції США говорить: «право людей на зберігання і носіння зброї не повинно обмежуватися». Своїм конституційним правом користуються 7 з 10 дорослих американців, на руках близько 150 мільйонів одиниць зброї [Трунов, 2004]. Будь- які обмеження в цій сфері зазіхають на конституційні права громадян. При цьому навіть драматичні інциденти з вогнепальною зброєю не змінюють ставлення американців до цього питання. [Корнієць, 2011: c. 91].

Як приклад, міське управління міста Кеннесо (Джорджія) зобов'язало глав домашніх господарств тримати принаймні одну одиницю вогнепальної зброї. За 16 років застосування цього акту в місті сталося три вбивства: два за допомогою ножа (1984 i 1987) і одне з використанням вогнепальної зброї (1987) [Трунов, 2004], а після того як закон вступив в силу в 1982 році, кількість злочинів проти особистості в Кеннесо скоротилося на 74 відсотки в порівнянні з 1981 роком, а в 1983 році — ще на 45 відсотків у порівнянні з 1982-м, і з тих пір залишається вражаюче низькою. Рівень злочинності в Кеннесо знизився тільки від усвідомлення того факту, що все міське товариство озброєне. Аналогічна постанова про обов'язкове озброєння була прийнята в 2001 році в місті Верджин, штат Юта [Карамаев, 2004].

Приклад штату Кеннесо можна розглядати як взірець адміністративно-правового забезпечення в цій сфері, за яким дійсно вдалося підвищити рівень громадського порядку i безпеки, але все ж таки, ми підтримуємо думку про те, що він є винятком з правила. 3 точки зору прихильників HGC, зброя — це абсолютне зло і головна причина насильства. I тому в своїх інформаційних кампаніях про Кеннесо вони намагаються про це не згадувати [Карамаев, 2004]. Логічним є висновок про те, що ліберальні прояви в побудові державного регулювання в сфері обігу та застосування зброї в США зумовлені саме соціальним інтересом населення, в контексті забезпечення їхньго гарантованого конституційного права.

23 жовтня 2005 року в Бразилії майже 64\% повнолітніх бразильців (59,1 млн. осіб) проголосували проти заборони продажу вогнепальної зброї в ході проведеного загальнонаціонального референдуму. Підсумки референдуму дозволяють кожному досягнув- 
шому 25 років бразильцеві мати вогнепальну зброю для самооборони або полювання. Дозвіл на придбання зброї дається Федеральною поліцією і оновлюється протягом кожних трьох років. Цей випадок засвідчує, що громадяни самостійно в змозі вирішити найгострішої соціальної проблеми, а саме, вуличної злочинності [Подборка фактов, 2006].

Швейцарія професійну армію замінила прямим озброєнням народу. Закони Швейцарії зобов'язують кожного громадянина зберігати вдома, як мінімум, автоматичну гвинтівку, яку йому видає держава [Трунов, 2004]. При звільненні в запас з армії швейцарці зберігають зброю у себе вдома. Керівництво країни, населення якої налічує шість мільйонів чоловік, не тільки дозволяє володіння зброєю і його вільне носіння, але і вітає його придбання. На даний момент на руках у приватному володінні знаходяться близько двох мільйонів одиниць вогнепальної зброї (зброя є у кожного третього швейцарця), з яких 600000 автоматичних гвинтівок і 500000 пістолетів. Поряд з цим рівень злочинів із застосуванням вогнепальної зброї настільки незначний, що поліцією навіть не ведеться статистика подібних злочинів. [Мурдов, 2000]. Тим самим, Швейцарія $є$ однією з найбільш озброєних країн Свропи.

У Федеральній Республіці Німеччина порядок придбання, зберігання та використання вогнепальної зброї громадянами регламентовано законом про зброю від 06.03.1976. На руках у громадян Німеччини перебуває 10 мільйонів одиниць легальної зброї. При одночасному зростанні кількості легального зброї загальне число злочинів, пов'язаних із застосуванням зброї, за період з 1971-го по 1994 рік скоротилася на 60\% [Подборка фактов, 2006].

Відповідні закони також дозволяють зберігання і носіння вогнепальної, в тому числі нарізної зброї в Латвії, Литві, Молдавії, Угорщини, Болгарії і т.д. У всіх перерахованих країнах після дозволу носіння і зберігання громадянського нарізної зброї був зафіксований значний спад тяжких злочинів. У всіх країнах, населення яких володіє цивільним нарізною зброєю, заборонені для цивільного обороту розривні кулі, кулі зі зміщеним центром ваги, кулі з мідними наконечниками, кулі з залитої тефлоном внутрішньою порожниною. Ведеться спеціальний регістр поліції - кулегільзотека. 3 зареєстрованого на фізичну особу зброї, в присутності поліцейського експерта виробляються два постріли. Стріляні гільзи і кулі долучаються до реєстру і зберігаються в поліції [Трунов, 2004].

Тобто, легалізація застосування зброї для самозахисту є вкрай актуальною для багатьох країн світу. Спостерігаючи статистичні данні, виникає висновок про те, що заборонивши вільний обіг зброї та посиливши нагляд та контроль за ії̈ застосуванням, зростає число тяжких злочинів. Статистика підтверджує, що там, де приватним громадянам дозволяють володіти зброєю злочинність падає, і особливо швидко скорочується число злочинів з використанням вогнепальної зброї.

В той же час, аналіз адміністративно-правового забезпечення обігу та застосування зброї в космосі на міжнародному рівні засвідчує зовсім іншу картину.

По-перше, Резолюція 3314 (XXIX) дає визначення агресії тільки на Землі. Відсутнє визначення агресії у космосі [Definition of Aggression, 1974].

По-друге, в Деклараціях Конференції Організації Об’єднаних Націй з проблем навколишнього середовища, прийнятих в Стокгольмі 16 червня 1972 і в Ріо-де-Жанейро 14 червня 1992, відсутні визначальні принципи співробітництва між державами у космічній галузі [Definition of Aggression, 1974; Rio Declaration, 1992]. На наш погляд саме тому, у «Конвенції про заборону військового або будь-якого ворожого використання за- 
собів впливу на природне середовище» космічний простір згадується опосередковано, у Статті 2 [Convention, 1977].

По-третє, під егідою ООН тільки розробляється проект «Міжнародного кодексу поведінки в космосі» [DRAFT, 2015]. Аналіз Проекту не дозволяє визначити стратегію розробки правового регулювання обігу зброї в космосі.

В цілому, аналіз резолюцій $\mathrm{OOH}$, а також літератури, яка розглядає міжнародно-правове регулювання військово-космічної діяльності, а також адміністративно-правове забезпечення обігу та застосування зброї в космосі, дозволяє зробити наступний висновок: резолюції Генеральної Асамблеї у космічній діяльності мають обмежений законодавчий статус. Вони не мають квазі-законодавчої сили у розумінні Річарда Фалька.

\section{Висновки}

Усе вище викладене дає можливість сформулювати наступні висновки:

1. Найактивнішим суб'єктом в сфері дослідження проблем обігу та застосування зброї в світі є Організація Об’єднаних Націй. Саме її резолюції визначають стратегію розвитку адміністративно-правового забезпечення обігу та застосування зброї на Землі.

2. Аналіз резолюцій Організації Об'єднаних Націй, а також літератури, яка розглядає адміністративно-правове забезпечення обігу та застосування зброї в космосі, дозволяє зробити висновок, що резолюції Генеральної Асамблеї у космічній діяльності мають обмежений законодавчий статус. Вони не мають квазі-законодавчої сили у розумінні Річарда Фалька, тому не визначають стратегію розвитку світового правового порядку, який забезпечує обіг та застосування зброї в космосі.

3. Необхідно створити таку правову базу та механізми, які не лише чітко регулюватимуть дане питання, а й передбачатимуть сувору відповідальність за не дотримання цих норм.

\section{Література}

Антонов, А. И. Международно-правовое регулирование военно-космической деятельности. Вестник МГИМО-Университета. №4 (25), 2012.

Романов, О. Міжнародно-правове регулювання обігу зброї у світі та національний досвід України / О. Романов // Юридичний журнал. 12, 2005: С.36-45.

Цивільна зброя в Україні: міфи та реальність. Украӥнська дійсність і міжна- родний досвід легалізації та контролю / Г. Ф. Герега, О.О. Зарубінський, Б. М. Петренко, Р. В. Старовойтенко. — К: Видавничий дім “АДЕФ-Україна”, 2015. - 152 с.

Корнієць, А. В. Зарубіжний досвід функціонування адміністративно-правових режимів обігу зброї та вибухових речовин/ А. В. Корнієць. // Проблеми правознавства та правоохоронної діяльності. 2, 2011: с. 88-93.

Параниця, С. П. Адміністративно-правові засади обігу зброї та пристроїв для відстрілу патронів, споряджених гумовими снарядами : автореф. дис... канд. юрид. наук: 12.00.07 / С.П. Параниця ; Нац. ун-т держ. податк. служби України. - Ірпінь, 2009. - $21 \mathrm{c.}$

Трунов, И. Гражданское оружие правозащиты. Право и политика. 7, 2004. http://guns. orenburg.biz/art008.html

Подборка фактов о гражданском оружии. 2006. http://guns.orenburg.biz/art999.html 
Карамаев, С. Автоматы возвращаются в магазины. В США отменен закон, запрещающий продажу полуавтоматического оружия. Lenta.Ru / 14 сентября 2004 года. http://guns.orenburg.biz/art011.html

Мурдов, Сайяд. Наличие оружия у законопослушных психически здоровых граждан фактор социальной стабильности магазины. «Круг жизни» / 16 октября 2000 года, № 16 (51) http://guns.orenburg.biz/art001.html

Convention on the Prohibition of Military or Any Other Hostile Use of Environmental Modification Techniques. Geneva, 18 May 1977. http://www.un-documents.net/enmod. htm

Declaration of the United Nations Conference on the Human Environment. Stockholm, June 1972. http://www.un-documents.net/unchedec.htm

Definition of Aggression. Resolution adopted by the General Assembly 3314 (XXIX). 14 December 1974. http://www.un-documents.net/a29r3314.htm

Draft articles on the effects of armed conflicts on treaties, with commentaries. 2011. http:// legal.un.org/ilc/texts/instruments/english/commentaries/1_10_2011.pdf

DRAFT International Code of Conduct for Outer Space Activities. May 2015. https:// papersmart.unmeetings.org/media2/7650867/annex_draft-code-of-conduct_may2015.pdf

Falk, Richard. On the Quasi-Legislative Competence of the General Assembly. American Journal of International Law. Volume 60, Issue 4 October 1966, pp. 782-791. https:// doi.org/10.2307/2196928

Rio Declaration on Environment and Development. 14 June 1992. http://www.un-documents. net/rio-dec.htm

\section{[ㅁ] References}

Antonov, A.I. Mezhdunarodno-pravovoe regulirovanie voenno-kosmicheskoy deyatelnosti. Vestnik MGIMO-Universiteta. \#4 (25), 2012.

Romanov, O. MIzhnarodno-pravove regulyuvannya obIgu zbroYi u svItI ta natsIonalniy dosvId UkraYini / O. Romanov // Yuridichniy zhurnal. 12, 2005: S.36-45.

TsivIlna zbroya v UkraYinI: mIfi ta realnIst. UkraYinska dIysnIst I mIzhna- rodniy dosvId legalIzatsIYi ta kontrolyu / G.F. Gerega, O.O. ZarubInskiy, B.M. Petrenko, R.V. Starovoytenko. - K: Vidavnichiy dIm “ADEF-UkraYina”, 2015. — 152 s.

KornIEts, A.V. ZarubIzhniy dosvId funktsIonuvannya admInIstrativno-pravovih rezhimIv obIgu zbroYi ta vibuhovih rechovin/ A. V. KornIEts. // Problemi pravoznavstva ta pravoohoronnoYi dIyalnostI. 2, 2011: s. 88-93.

Paranitsya, S. P.. AdmInIstrativno-pravovI zasadi obIgu zbroYi ta pristroYiv dlya vIdstrIlu patronIv, sporyadzhenih gumovimi snaryadami : avtoref. dis... kand. yurid. nauk: 12.00.07 / S.P. Paranitsya ; Nats. un-t derzh. podatk. sluzhbi UkraYini. — IrpIn, 2009. - $21 \mathrm{~s}$.

Trunov, I. Grazhdanskoe oruzhie pravozaschityi. Pravo i politika. 7, 2004. http://guns. orenburg.biz/art008.html

Podborka faktov o grazhdanskom oruzhii. 2006. http://guns.orenburg.biz/art999.html

Karamaev, S. Avtomatyi vozvraschayutsya v magazinyi. V SShA otmenen zakon, zapreschayuschiy prodazhu poluavtomaticheskogo oruzhiya. Lenta.Ru / 14 sentyabrya 2004 goda. http://guns.orenburg.biz/art011.html 
Murdov, Sayyad. Nalichie oruzhiya u zakonoposlushnyih psihicheski zdorovyih grazhdan faktor sotsialnoy stabilnosti magazinyi. «Krug zhizni» / 16 oktyabrya 2000 goda, \# 16 (51) http://guns.orenburg.biz/art001.html

Convention on the Prohibition of Military or Any Other Hostile Use of Environmental Modification Techniques. Geneva, 18 May 1977. http://www.un-documents.net/enmod. $\mathrm{htm}$

Declaration of the United Nations Conference on the Human Environment. Stockholm, June 1972. http://www.un-documents.net/unchedec.htm

Definition of Aggression. Resolution adopted by the General Assembly 3314 (XXIX). 14 December 1974. http://www.un-documents.net/a29r3314.htm

Draft articles on the effects of armed conflicts on treaties, with commentaries. 2011. http:// legal.un.org/ilc/texts/instruments/english/commentaries/1_10_2011.pdf

DRAFT International Code of Conduct for Outer Space Activities. May 2015. https:// papersmart.unmeetings.org/media2/7650867/annex_draft-code-of-conduct_may2015.pdf

Falk, Richard. On the Quasi-Legislative Competence of the General Assembly. American Journal of International Law. Volume 60, Issue 4 October 1966, pp. 782-791. https:// doi.org/10.2307/2196928

Rio Declaration on Environment and Development. 14 June 1992. http://www.un-documents. net/rio-dec.htm 